IKONOMIKA: Jurnal Ekonomi dan Bisnis Islam

Volume 3, No. 2 (2018.)

ISSN : 2527-3434 (PRINT) - ISSN: 2527-5I43 (ONLINE)

Page : I67 - I76

\title{
The Influence of Serious Attitude In Work towards Business Success (Metro Muslim Entrepreneurs)
}

\author{
Suraya Murcitaningrum ${ }^{1}$, Muhammad Machsun ${ }^{2}$, Ibrahim Aliyu Gololo ${ }^{3}$ \\ IAIN Metro ${ }^{1}$, Muhammadiyah University ${ }^{2}$, University Gadau, Bauchi, Nigeria ${ }^{3}$ \\ machsun7810@gmail.com², aliyugololo2@gmail.com ${ }^{3}$
}

\begin{abstract}
This paper discusses thei nfluence of seriousattitude in work towards business success of Muslim entrepreneurs as it is known that the seriousness in work can create business success. The purpose of this study is to identify and assess the effect of seriousness attitude in work toward the success of the Muslim entrepreneurs in Metro Regency of Lampung. This study is based on a literature study and understandings of the accumulation of various primary studies conducted on Muslim entrepreneurs around the Islamic Boarding School of Al Muhsin 28 Metro collected through questionnaires. The literature study was conducted to understand the concept of the seriousness in work. The results of the analysis showed that the significant value was 0.020 . Since the value of $\alpha=0.01$, then the $H_{0}$ was rejected if $\alpha$ was $<0.01$. Based on the analysis, it can be concluded that there is a relation of seriousness in work of Muslim businessmen to business success in Metro Regency.
\end{abstract}

Keywords : Serious Attitude,Work towards Business Success, Muslim Entrepreneurs

\section{A. INTRODUCTION}

Allah SWT created humans with the aim solely to serve and worship him (Rozalinda: 2016, I) that every single work a person do is always dedicated to Allah. As stated in the Al Quran Surat Az-Zariyat: 56 meaning 'and not I only created jinn and mankind except to worship to me".

According to (Muhammad Ismail Yusanto and Muhammad Karebet Widjajakesuma, 2002;II4) Islam encourages every Muslim to always work hard and earnestly devote strength and ability to work. For Muslims, to work in the view of Islam is a part of worship and an implementation of one obligation. In addition, (Hamdi Agustin, 20I7: I4) said that all business activities are religious in making a living, and this should not detract a person from worshipping Allah.

(Quraish Shihab, 20I2) mentioned that to work with full sincerity, slick, and not glossed over as mentioned in the hadith that 'Allah is happy when one of you do a job accurately". It is also explained in another hadith that the Prophet 
Muhammad conveyed to the angel Gabriel about the meaning of good deed as "Ihsan is to worship Allah as if you are seeing Him, if not, then be sure that Allah watches you". It is very clear that working with sincerity (planned, structured, and measurable) would result in the desired goal.

Some previous research about work have been done among others are by Choirul Huda. His study entitled Work Ethic of Muslim Entrepreneurs (study on Muslim businessmen of alumnus of IAIN Walisongo) mentioned that a good work ethic will lead an entrepreneur to the success of the business. Entrepreneurship demands work ethic to work hard and independently in order to achieve success. Islam teaches to hard work, self-reliance (biyadihi), and not whiny.

In addition, the research results from Hasnah Rimiyati \& Munjiati Munawaroh entitled Effect of Application Values of Islamic Entrepreneurship towards Business Success. A Study on SME Muslim Entrepreneurs in Yogyakarta states that the variable of application of the values of islamic entrepreneurship such asto value honesty, hard work, reliable, order administration, obedient to pay zakat, and alms together significantly influence the success of the business.

Further, Bagus Mohamad Ramadan explained that Islamic work ethic on Muslim traders in Pasar Besar Madiun gave positive impact on business performance. The implementation of Islamic work ethic can be seen through the nine aspects of the Islamic work ethic which includes: to value time, to have a clean morality, to commit to steadfastness and powerful stance, to be consistent and courage to face challenges, to be creative, resilient and unyielding, to ensure hospitality service and to have the spirit of change.

Rahmani Timorita Yulianty and Mega Octaviani in their research entitled The Influence of Religion and Culture on Muslim businessmen work ethic in Bugis tribe in northern Kalimantan of Nunukan District explained that the religious forces in an entrepreneur's work ethic have a huge role. Without religious teaching, a business would not run well. Even if there is a case of an entrepreneur avoiding the law, in certain extent it should apply certain religious values though not in perfect sense. The influence of the Islam as a religion for the Bugis businessman was noted significant in their business activity. Among the interesting features is that they feel ashamed if not being productive. Most of them think to get a job as soon as they finished their study, be it either becoming an employee or working on family business.

This research reviewed the previous studies but done in Muslim businessmen who are from Islamic boarding school environment that has 
understood and practiced Islamic law but of different location of respondents. Based on that grounds, this study is to get the relevant information related to its implementation inMuslim businessmen in Metro Regency.

The number of Muslim population in Metro Regency is 2015, I48.060 people. The city data (2017) showed that this city has a number of micro enterprises amounting 68II, with 925 small businesses, and 96 medium scale enterprises. Those Muslim businessmen of Metro city are of diverse backgrounds but has been able to maintain their business until now through sincerity in doing business.

To obtain a general overview of the factual condition of Muslim businessmen work seriousness influence on the success of their business, researchers conducted an initial survey in 30 Muslim businessmen around the Islamic Boarding School Al Muhsin 28 of Metro. It was conducted to determine the extent of the influence of Muslim businessmen sincerity to work towards the success of the business.

\section{B. THEORETICAL FRAMEWORK}

For Muslims, the basic value ofwork or charity is the intention to worship God. This value differentiates an act to be considered good deed or not. Affirmed that is an obligation to every man to do his best to assume the mandate and responsibilities because God will not burden someone with something that is not capable of doing (QS. Al-Baqarah 2; 286). As also mentioned in (QS. Al-Kahf I8; II0), which means 'For those who believe and work well will be of hayatantayyibah (good life) and get a chance to meet Him (Allah)'.

So that the Islamic conception of the work is a thorough religious obligation upon every Muslim. (Ali Hasan 2009; 73) said that to work is to worship. (Hamdi Agustin,2017: I6), also said that worship to God should be done by a Muslim by doing things which is commanded and is not forbidden by God. Working as a worship is done to meet the needs in a good way and in accordance with the existing Islamic guidance. For all that we do will be held accountable in hereafter. Moreover, (Dwi Suwiknyo, 2010; 76) stated that the work is all forms of activities that bring benefits both material and non-material. Further she stated that many people would regard an activity that is part of the job or not be seen from the material. But Islam taught that work is not only activities which might be of worldly but also has transcendence value. 
The Influence of the Serious Attitude in Worktowards Business Success

(Study of Muslim Entrepreneurs in Metro Regency of Lampung Province)

(Suraya Murcitaningrum ${ }^{1}$, Ibrahim Aliyu Gololo ${ }^{3}$ )

(Ali Hasan, 2009; 70) said that all human life will continue to work because humans encounter various difficulties. The strength of the motivation to work in Islam is known as the spirit of fastabi qul khairat to find human needs either physical, psychological, and social. Then (Jusmiali said in the book 'Bisnis Berbasis Syariah, 2008: 37), By working, individuals can meet the intent of his life and the lives of his family. Furthermore, he said that a Muslim is really required to work for the life of his world and the afterlife (2008: 37). (Ali Hasan,2009:73), that works for Muslims would not only based on the goals that are world alone. Moreover, work is worship. He said that by working hard, place of humanity will be lifted, as to work is a way for Muslims to get a blessing from God. (Hamdi Agustin,2017: 17) mentioned that Islam very appreciates the hard work of a person who wages the hard work rewarded by Allah. And the consequences of a Muslim work, and invest in finding rizqi should refer to the Al-Qur'an and the hadith.

Islam does not encourage his people just to work, but also order to work diligently and well. Work sincerity supported the optimal knowledge and skills as well as finish perfectly. (Muhammad Ismail Yusanto and Muhammad Karebet Widjaja kesuma, 2002; I04), added other values askafa'ah (proficient in the skill of work), himmatul-'amal (having a high spirit in the works), and trustworthy.

\section{RESEARCH METHODS}

As a field research, this study used survey method with quantitative approach. Furthermore, this research worked with businessman in Metro, mainly the Muslim entrepreneurs around the Islamic Boarding School Al-Muhsin 28. The data collection techniques used in this research are the primary data source which were about the variables of sincerity to work collected through a questionnaires distributed directly to Muslim businessmen. The secondary data sources used in this study are the data obtained through the study of literature. While the data collection in this research was done through survey by distributing questionnaires to describe the indicator variables studied. Further, the testing instrument was done using SPSS I9.

\section{RESULTS AND DISCUSSION}

Here is a description of the Influence of seriousness in workof Muslim businessmen towards thier business success in the Metro. 
IKONOMIKA

Volume 3, Nomor 2 (2018)

Table I

The Entrepreneur' Group *seriousness Work Cross tabulation Count

\begin{tabular}{|ll|r|r|r|}
\hline \multirow{2}{*}{} & & \multicolumn{2}{|c|}{$\begin{array}{c}\text { RESULTS Data } \\
\text { processing }\end{array}$} & \multirow{3}{*}{} \\
\cline { 3 - 4 } & & $\begin{array}{c}\text { Not } \\
\text { optimal }\end{array}$ & Optimal & Total \\
\hline Entrepreneur & CONTROL & I2 & I8 & 30 \\
GROUPS & EXPERIMENT & 4 & 26 & 30 \\
Total & & I6 & 44 & 60 \\
\hline
\end{tabular}

The output above is the result of the implementation of after sincerity to work applied, wherein for the control groups there were 12 employer optimal results of operations or works, while for other employer groups were 4 employers who were not optimal in the work. Based on these results it can be said that the application of seriousness in work gave rise to business success. For the next will be tested against the results of the study.

\section{Testing Among Different Groups Entrepreneurs}

$\mathrm{H}_{a}$ : There is a difference application of seriousness of work of Muslim entrepreneurs towards business success in Metro

$\mathrm{H}_{0} \quad$ : No Difference application of seriousness of work of Muslim entrepreneurs towards business success in Metro

Table 2

Independent Samples Test

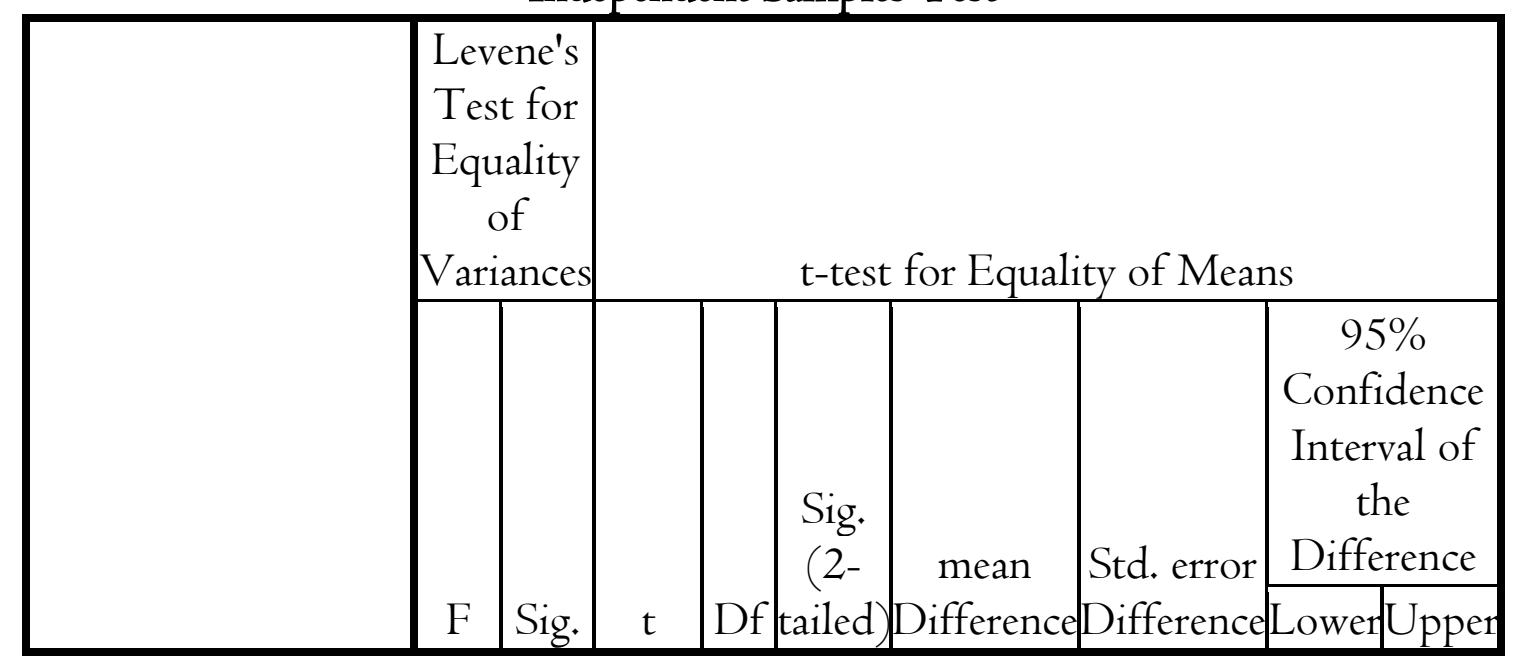


The Influence of the Serious Attitude in Worktowards Business Success

(Study of Muslim Entrepreneurs in Metro Regency of Lampung Province)

(Suraya Murcitaningrum ${ }^{\mathrm{I}}$, Ibrahim Aliyu Gololo ${ }^{3}$ )

\begin{tabular}{|c|c|c|c|c|c|c|c|}
\hline $\begin{array}{l}\text { RESULTSEqual } \\
\text { seriousness variances } \\
\text { Work } \\
\begin{array}{ll}\text { assumed } \\
\\
& \text { Equal } \\
& \text { variances } \\
& \text { not } \\
& \text { assumed }\end{array}\end{array}$ & .864 & $.357 / 3,403$ & \multicolumn{2}{|c|}{\begin{tabular}{|l|l|}
58 & .001 \\
57 & .001
\end{tabular}} & $\begin{array}{l}8667 \\
8667\end{array}$ & $\begin{array}{l}2,547 \\
2,547\end{array}$ & \begin{tabular}{|}
3,569 \\
3,568
\end{tabular} \\
\hline
\end{tabular}

Based on SPSS output above it can be seen that significant value is 0.001 . If we use $\alpha=0.0 \mathrm{I}$, and $\mathrm{H}_{0}$ will be rejected if $\alpha<0.0 \mathrm{I}$. So based on the results of the above output researcher rejects $\mathrm{H}_{0}$ for values $\alpha<0.0 \mathrm{I}$ namely $0.00 \mathrm{I}$. There is a difference effect of application of seriousness of work of Muslim entrepreneurs towards business success in Metro

Based on the above output we can see the results of using the homogeneity test Levene's Test for Equality of Variances with the formulation of hypotheses $\mathrm{H}_{\mathrm{a}}$ : Not Homogeneous

$\mathrm{H}_{0}$ : Homogeneous

Based on the SPSSdata above, it can be known that significant value is 0.357 . If we use $\alpha=0.0 \mathrm{I}$, and $\mathrm{H}_{0}$ will be rejected if $\alpha<0.0 \mathrm{I}$. So based on the results of the above output $H_{0}$ researchers received for value $\alpha>0.05$ is 0.357 . This means that the data is homogeneous.

\section{Table 3}

Tests of normality

\begin{tabular}{|l|r|r|r|r|r|r|}
\hline & \multicolumn{3}{|c|}{ Kolmogorov-Smirnova } & \multicolumn{3}{c|}{ Shapiro-Wilk } \\
\cline { 2 - 7 } & statistics & \multicolumn{1}{c|}{ Df } & \multicolumn{1}{c|}{ Sig. } & statistics & \multicolumn{1}{c|}{ df } & \multicolumn{1}{c|}{ Sig. } \\
\hline RESULTS & .168 & 60 & .000 & .948 & 60 & .012 \\
Implementatio & & & & & & \\
n Working \\
Seriousness
\end{tabular}

\section{Significance Lilliefors Correction}

Based on the above output we can see the results of the test for normality using Shapiro-Wilk. With the formulation of hypotheses

$\mathrm{H}_{a}$ : Abormal

$\mathrm{H}_{0}$ : Normal 
The data indicated that the significance value was 0.0I2. If we use $\alpha=0.0 \mathrm{I}$, and $\mathrm{H}_{0}$ will be rejected if $\alpha<0.01$. So based on the results of the above output $\mathrm{H}_{0}$ researchers received for value $\alpha>0.0 \mathrm{I}$ is 0.0I2. This means that the data is normal.

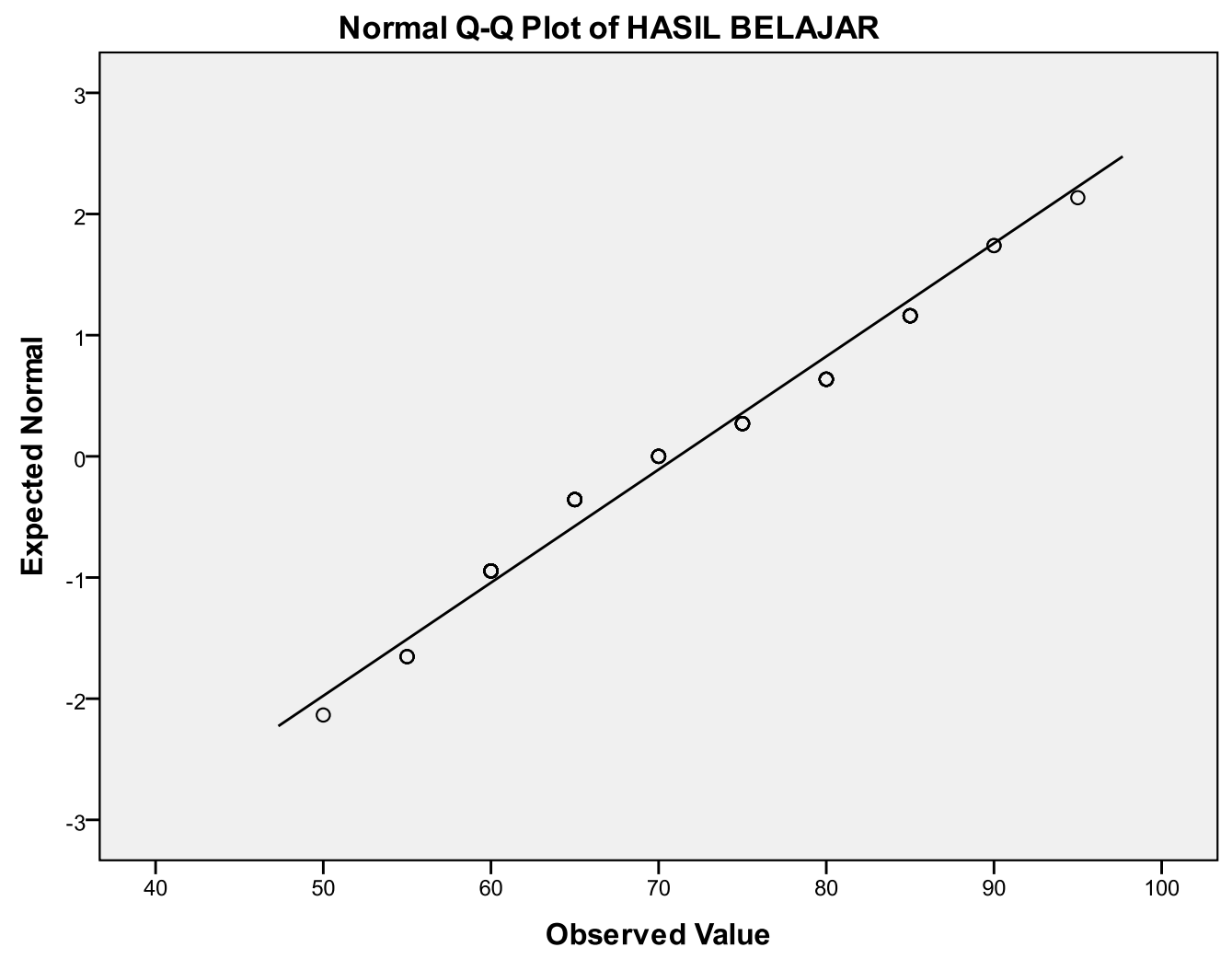

It can also be understood on the normal QQ plot above the normal spread of data can be seen from the spread distribution points around the line.

Table 4

Chi-Square Test

The Entrepreneurs' Group * result seriousness Work

Crosstabulation

Count

\begin{tabular}{|c|c|c|c|}
\hline & \multicolumn{2}{|c|}{ Test results } & \multirow[b]{2}{*}{ Total } \\
\hline & $\begin{array}{c}\text { Not } \\
\text { optimal }\end{array}$ & Optimal & \\
\hline CONTROL & & 18 & 30 \\
\hline
\end{tabular}




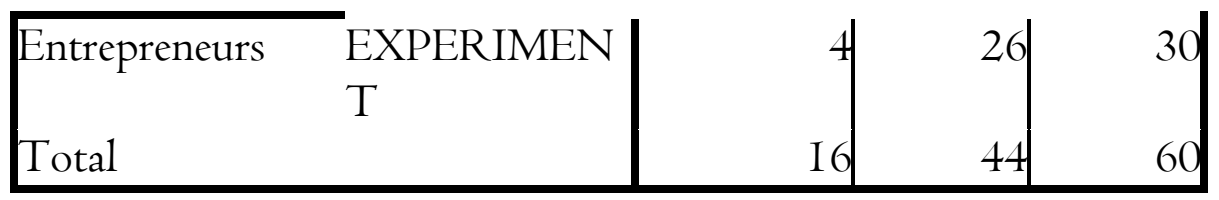

$\mathrm{H}_{a} \quad$ : There is a relation between application of seriousness of work of Muslim entrepreneurs towards business success in Metro

$\mathrm{H}_{0} \quad$ : No relation of application of seriousness of work of Muslim entrepreneurs towards business success in Metro

\section{Table 5}

Chi-Square Tests

\begin{tabular}{|c|c|c|c|c|c|}
\hline & Value & Df & $\begin{array}{l}\text { Asymp. Sig. } \\
\text { (2-sided) }\end{array}$ & $\begin{array}{c}\text { Exact Sig. (2- } \\
\text { sided) }\end{array}$ & $\begin{array}{c}\text { Exact Sig. (I- } \\
\text { sided) }\end{array}$ \\
\hline Pearson Chi-Square & $5.455 \mathrm{a}$ & 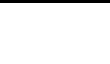 & .020 & \multirow{6}{*}{.039} & \multirow{6}{*}{.020 } \\
\hline Continuity & 4,176 & & .04I & & \\
\hline Correctionb & \multirow{4}{*}{5649} & & \multirow{4}{*}{.017} & & \\
\hline likelihood Ratio & & & & & \\
\hline Fisher's Exact Test & & & & & \\
\hline$N$ of Valid Cases & & & & & \\
\hline
\end{tabular}

The SPSS data output above show that the significant value is 0.020. If we use $\alpha=0.0 \mathrm{I}$, and $\mathrm{H}_{0}$ will be rejected if $\alpha<0.0 \mathrm{I}$. So based on the results of the above output researcher rejects $H_{0}$ for values $\alpha<0.0$ I namely 0.020. Meaning There is a relation between seriousness of workof Muslim entrepreneurs towards business success in Metro.

\section{E. CONCLUSION}

Based on data compiled from a variety of information respondents, it can be concluded that there is a relationship between the application of seriousness of work of Muslim entrepreneurs towards business success in Metro. It can be seen from the significant value of 0.020. If we use $\alpha=0.0 \mathrm{I}$, and $\mathrm{H}_{0}$ will be rejected if $\alpha$ $<0.01$. So based on the results of the above output researcher rejects $H_{0}$ for values $\alpha<0.0$ I namely 0.020 . 


\section{REFERENCES}

Ali Hasan, 2009, Manajemen Bisnis Syariah, Yogyakarta, Pustaka Pelajar.

Bagus Mohamad Ramadhan. Journal JESTT Vol. 2 No. 4 April 2015

Dwi Suwiknyo, 2010, Kompilasi Tafsir ayat-ayat Ekonomi islam, Yogyakarta:

Hamdi Agustin, 2017, Studi Kelayakan Bisnis Syariah, Depok, Raja Grafindo

Persada.

Hasnah Rimiyati \& Munjiati Munawaroh Vol 7, No 2 September 2016.

Jusmaliani, 2008, Bisnis Berbasis Syariah, Jakarta, Bumi Aksara.

Muhammad Ismail Yusantodan Muhammad Karebet Widjaja Kesuma, 2002, Menggagas Bisnis, Jakarta, Gema Insani Pers .

Purnamasari, F. (2017). Pertumbuhan Ekonomi: Investasi Pemerintah Dan Manajemen Investasi Dalam Perspektif Islam (Studi Di Kabupaten/Kota Provinsi Lampung). Jurnal Manajemen Indonesia, I7( I), I3-26

Pustaka Pelajar.

Rahmani Timorita Yulianty dan Mega Octaviani. Pengaruh Agama dan Budaya terhadap Etos Kerja Pebisnis Muslim Suku Bugis di Kabupaten Nunukan Kalimantan Utara. Jurnal Millah Vol. XIV, No. I, Agustus 2014.

Rozalinda, 2016, Fikih Ekonomi Syariah Prinsip Syariah Dan Implementasinya Pada Sektor Keuangan Syariah, Jakarta, Raja Grafindo Persada. 
The Influence of the Serious Attitude in Worktowards Business Success

(Study of Muslim Entrepreneurs in Metro Regency of Lampung Province)

(Suraya Murcitaningrum ${ }^{\mathrm{I}}$, Ibrahim Aliyu Gololo ${ }^{3}$ )

https://ejournal.radenintan.ac.id/index.php/ikonomika 